\title{
Narratological Analysis of Temporality in Novel
}

\author{
Nasr M. A. Abdulrraziq ${ }^{1)}$, Ayman E. M. Geedallah ${ }^{2)}$ \\ 1), 2) University of Tobruk, Faculty of Arts, English Language Department
}

Email: nasr77.tobruk@gmail.com

\begin{abstract}
This paper definitely attempts to intermingle them with regard to structural analysis. It adopted the theory of Gerard Genette, the analysis of the famous novel Great Expectations by Charles Dickens, the main discussion concerns order and duration whereas frequency is ruled out. Consequently, order can be presented by two different narrative techniques; through the profound analysis of analepsis and prolepsis to show the chronological and anachronological order of the novel. A further analysis of the novel also includes the alternation of the four narrative movements of duration which are divided into techniques of deceleration; descriptive pause and scene whereas techniques of accelerations; ellipsis and summary. The diagrams and tables of the study aim to reach semi-statistical deduction for the chronological techniques of anachronism and its effect on the structure of the narrative time of the novel as whole, which gives a general idea about the system of the time in novel.
\end{abstract}

Keywords: Narratological, Novel, Charles Dickens

\section{Introduction}

This paper attempts to extend some interpretations about the analepsis and prolepsis in Great Expectations and also determine precisely the duration through the accelerated techniques, ellipsis and summary and decelerated ones through scene and descriptive pause. Although the example's calculations were proximate not comprehensively accomplished, the results will be very nearly precise. In addition, the analysis of Great expectations is the analysis of the relationships of the story elements, notably between story time and narrative time. The term narratology began to appear in 1966 in the same year that the French journal "Communications" brought out a special issue entitled "the structural analysis of narrative" after three years, the term "narratology" was coined by one of the most famous contributors, Tzvetan Todorov (1969) who defines that narratology as the theory of structures of narrative in order to investigate and analyze a narrative phenomena into their component parts and then attempts to determine functions and relationships. Crystal (1997) also agrees with Todorov's definition, clarifying that the structural study of narrative is known as narratology. Structural elements are proposed, such as those which initiate a narrative as a summarizing abstract, a story orientation or those which close it such as a closing summary, a narrator's evaluation. There is a focus on such notions as theme, plot, character, role, and point of view, especially in studies of literary narrative.

Furthermore; Onega and Landa (1996) add that narratology is the science of narrative. The term was symplified by such structuralist critics as Gérard Genette, Mieke Bal and others in the 1970s. As a result, the definition of narratology has been restricted to structural, or structuralist, analysis of narrative (Onega and Landa,1996). 
Holman(1972) explains narration may exist, entirely by itself, but it is most likely to incorporate with it considerable description. There are two forms of narration: simple narrative, which is content to recite an event or events and is largely chronological in its arrangement of details, and the second type of narration is narrative with plot, which is less often chronological and more often arranged according to a preconceived artistic principle determined by the nature of the plot and the type of story intended (Holman,1972).

Crystal (1997) defines narrative, with a different point of view, as an application of the everyday use of this term, as part of the linguistic study of discourse, which aims to determine the principles governing the structure of narrative texts. "A narrative is seen as a recapitulation of past experience in which language is used to structure a sequence of real or fictitious events" (Crystal, 1997:254).

\section{Order and Duration}

Genette (1980) claims that time has the unique ability to structure a novel, it allows the reader to know from which the main point a story is being told. That is to say, story time is different from narrative time because is usually narrated in linear temporality. Therefore, once the story is denoted in the text, the story events may be arranged in a nonlinear way.

Genette divides the temporal relationships between story time and narrative time into three types: order, duration and frequency: We will study relations between the time of the story and the (pseudo-) time of the narrative according to what seem to me to be three essential determinations: connections between the temporal order of succession of the events in the story and the pseudo-temporal order of their arrangement in the narrative (Genette,1980:35)

The analepsis has previously been defined during the time of narrative as an interrupted event and a past one is inserted. Genette (1980) insists that a past occurrence is inserted which should be analyzed in terms of its reach and extent. Dickens's achievement of time at the beginning of his novel was puzzling by using two periods 'infant' when he started to pronounce his name and 'child conclusion' which mentioned in his manuscript '7 years'. He has an embarrassing description of time limit. Dickens doesn't offer any time or even dates at the beginning of his novel, he probably wants his readers to rely on the dispersion of temporal information by analyzing the way in which events and actions are temporally positioned and distributed in the narrative. Genette (1980).

Genette (1980) classifies prolepsis in the same way as he defines analepsis. It Involves the narration of a story-event before earlier events have been told. Prolepsis is different from merely alluding at a future occurrence; it is different from anticipation (Ba,1 1985). Genette (1980) says that it shouldn't be confused between anticipations, those will or won't happen and advance mentions those will happen and that "all prolepses are of the partial kind" often interrupted in as unexpected way as they were begun (Genette,1980). 
There is no way to provide neutral standard to measure text duration. Genette (1980) emphasisly proposes to use a steady speed rather than adjust to the story text, as the type against which to examine degrees of duration. Therefore, There are two forms of modification: acceleration and deceleration.

The effect of acceleration is produced by determining a short part of the text to a long period of the story, whereas the effect of deceleration is produced by the opposite procedure, namely determining a long part of the text to a short period of the story ( Rimmon-Kenan,1986).

Genette (1980) the category of duration is related to the idea of narrative speed, that is to say, the relationship between the duration of the story and the length of the text which includes four narrative movements: summary, descriptive pause, ellipsis and scene.

Genette (1980) goes on to mention the descriptive pause contributes to slowing down the narrative. The analysis of ellipses which means the story time is omitted. From a temporal point of view, ellipses such as, two years later, are said to be definite, and those like, some many years later. Indefinite, explicit ellipses arise from the indication definite or indefinite of the fall of time omitted, and implicit ellipses are understood from some chronological gap in narrative continuity. Finally, a certain parallel between the story and narrative time characterizes the narrative movement of the scene.

Rimmon-Kenan (1983) also goes to mention that the important consideration in the study of events is duration, that is to say, how long the event is; for example, it is assumed whether: it lasts an hour, a year or only a few minutes; focusing on the event probably could be measured in terms of 'long' or 'short'. Rimmon-Kenan (1986) also differentiates between ellipsis and descriptive pause. The maximum speed in ellipsis is omission, where zero textual space corresponds to some story duration. On the other hand, the minimum speed is showed as a descriptive pause, where some segment of the text corresponds to zero story duration.

Generally speaking, Rimmon-Kenan (1986) maintains that the most important events are described in detail, that is decelerated, whereas the less important events are compacted, that is accelerated. However, this is not always the case (Rimmon-Kenan,1986:56).

\section{The Novel}

Calder (1979) summarizes Great Expectations, saying that Pip tells his own story as an adult looking back on his younger years. When the novel begins, Pip may be a poor orphan who seems destined to become a blacksmith like his brother-in-law and live out his life within the marsh area of Kent, England. An unexpected chain of events, however, thrusts him into a totally different world and way of life. Over time, Pip's new life becomes far more complicated than he imagined it might be, and he's forced to reevaluate his values and therefore the values of the society during which he finds himself. (Calder,1979:11-13). 


\section{Data Analysis and Interpretation}

\subsection{First Expectation (Chapther 1, page 35 to Chapter 19, page 186)}

The narrator utilizes more than 13 pages in the three first chapters for events on the Christmas Eve $\neg$-all these pages for only one night. The events of the second day amounts to more than 9 pages in Chapter Four. This means that the story from page number 35, which is the beginning of the story, to page 73 occurred during two nights a total of 27 pages.

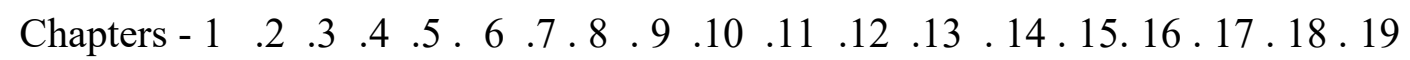

Figure 1. Time in the First Expectation

The summary of the story events which takes on 151 pages and covers a period of 7 years consists of 48 analepsis and 8 prolepsis; there is no more than one ellipsis , 28 descriptive pause and 107 scenes. The narrator decelerated the time of the story and 41 summaries in order to cover many actions.

Tabel 1. The Data of Order and Duration in the First Expectation

\begin{tabular}{llllllll}
$\begin{array}{l}\text { Chapter(s) } \\
\text { Pause Scene }\end{array}$ & Pages & Analepsis & \multicolumn{2}{c}{ Prolepsis } & \multicolumn{2}{c}{ Ellipsis } \\
$5 \ldots \ldots \ldots 1$ & 35 & 12 & 6 & $*$ & 12 & 14 & 23 \\
$10 \ldots \ldots \ldots 6$ & 37 & 19 & 1 & 1 & 7 & 7 & 24 \\
$15 \ldots \ldots . .11$ & 39 & 7 & 1 & $*$ & 9 & 3 & 26 \\
$20 \ldots \ldots 16$ & 39 & 10 & $*$ & $*$ & 13 & 4 & 34 \\
Total 150 & 48 & 8 & 1 & 41 & 28 & 107 &
\end{tabular}

From Chapter 5 up to Chapter 6, the events require in 13 pages, whereas chapter 7 narrates a full year. The spelling of Joe's name takes into 4 pages. Chapter 8 Pip and Estella play cards which requires five pages (from page number 88 up to page number 92). The events in Chapter 9 happen in two days, Chapter 10 in one day and Chapter 11 in one day.

At the beginning of Chapter 18, Dickens slows down the narrative for 4 years, utilizing implicit ellipsis because the narrator did not directly mention the time but the duration of time can be deducted from Chapter 19 when Pip was 14 years and in Chapter 39 Pip was apprenticed and the age of apprentice which was 18 years. The number of scenes in the first expectation which was 107 scenes covering 78 pages from chapter 1 up to Chapter 19.

To conclude, Dickens generally slows down the narrative time to make the reader from a complete picture about the story, especially, if the reader knows that many actions happened before the starting point of the story.

Second Expectation. Chapter 20, page 187 to Chapter 40, page 342. 


\subsection{Dickens starts to speed up somewhat in the Second Expectation}

Which consists of 79 scenes covering approximately 71 pages to give connecting dialogues from Chapter 20 up to chapter 39 in order to make the characters more clear and familiar for the reader.

Chapters 20.21 .22.23. 24 .25.26.27. 28. 29. 30.31.32.33.34.35.36.37. 38 .

Figure 2. Time in the Second Expectation

The events of the story occur on 155 pages, happen in 4 years consisting of 24 analepsis and 8 prolepsis, there is only one ellipsis, 5 descriptive pauses and 79 scenes that because the narrator decelerated the time of the story and 24 summaries to cover a lot of actions.

Table 2. The Data of Order and Duration in the Second Expectation

\begin{tabular}{|c|c|c|c|c|c|c|c|c|}
\hline \multirow{2}{*}{\multicolumn{3}{|c|}{$\begin{array}{c}\text { Chapter(s) N.Pages } \\
\text { Descriptive Pause }\end{array}$}} & \multirow{2}{*}{\multicolumn{2}{|c|}{$\begin{array}{l}\text { Analepsis } \\
\text { Scene }\end{array}$}} & \multirow{2}{*}{\multicolumn{2}{|c|}{ Prolepsis }} & \multirow[t]{2}{*}{ Ellipsis } & \multirow[t]{2}{*}{ Summary } \\
\hline & & & & & & & & \\
\hline $25 \ldots \ldots .20$ & 45 & 8 & 2 & 1 & 8 & 2 & 27 & \\
\hline $30 \ldots \ldots 26$ & 40 & 5 & 4 & $*$ & 4 & 1 & 16 & \\
\hline $35 \ldots \ldots 31$ & 32 & 7 & 1 & $*$ & 5 & 1 & 11 & \\
\hline $40 \ldots \ldots 36$ & 50 & 4 & 1 & $*$ & 7 & 1 & 25 & \\
\hline Total 167 & 24 & 8 & 1 & 24 & 5 & 79 & & \\
\hline
\end{tabular}

In conclusion, the events of the story require 155 pages to cover a period of time of 4 years; it consists of 24 analepsis and 8 prolepsis, there is only one ellipsis because Dickens still needs to explain more in regard to the previous actions in the story. Therefore, he used the shortage of the omissions of the previous expectation and used 5 descriptive pauses and 79 scenes and Dickens used 24 summaries in order to make the reader follow the actions and understand the story in general.

\subsection{Third Expectation (Chapther 40, page 342 to Chapter 59, page 493)}

In Second Expectation, Dickens mentions mention Pip's age, His age now is 23 years makes the reader realize the period of time which has passed, especially when the narrator previously mentioned the time in one night, "a few weeks, two days later". This made the reader confused decide the span of time, and the narrator rarely says the ages of the characters in a direct way. In Chapter 39, Pip is 23 years old and this means all the previous events happened in 16 years.

Chapters 40.41 .42 .43 .44 .45 .46 .47 .48 .49 .50 .51 .52 .53 .54 .55 .56 .57 .58 .59

Figure 3. Time in the Third Expectation 
From Chapter 39 up to Chapter 46 the narrator doesn't mention any long period of time; all the periods which are used are very short periods of time. During all the previous chapters, the narrator decelerated the action. At the beginning of Chapter 47 " some weeks passed without any change." Here the narrator utilizes the accelerated features such as summary and ellipsis. The Third and Final Expectation consisted of 51 scenes in 48 pages from chapter 40 up to chapter 59 which aimed to move the actions and events quickly.

Table 3. The Data of Order and Duration in the Third Expectation

Chapter(s) Pages Analepsis Prolepsis Ellipsis Summary Descriptive Pause Scene

$\begin{array}{llllllll}45 \ldots . .40 & 44 & 4 & 2 & * & 4 & 1 & 21 \\ 50 \ldots \ldots 46 & 32 & 3 & 1 & 1 & 2 & 2 & 11 \\ 55 \ldots . \ldots 50 & 45 & 2 & 1 & 2 & 1 & 1 & 10 \\ 59 \quad \ldots 56 & 28 & 6 & 1 & 2 & 1 & 4 & 7 \\ \text { Total } 149 & 15 & 5 & 5 & 8 & 8 & 47 & \end{array}$

To sum up, the events of the story require 150 pages to cover a period of 7 years; it consists of 48 analepsis and 8 prolepsis, there is no more than one ellipsis 8 descriptive pauses and 47 scenes and 8 summaries.

\section{Conclusion}

This paper principally shed some light on the anachronisms according to Gerard Genette's theory which has shown that the story events are generally arranged in chronological order, although Dickens sometimes organizes story events in nonlinear ways by using analepsis and prolepsis. In other words, the events of the story did not harmonize with time-arrangements; the events also were not systematic from the narratological point of view. The events were arbitrarily narrated without succession of the analepses, and the sequences of the events come according to necessity. The duration of Great Expectations by Charles Dickens covers approximately 28 years, consisting of on 59 chapters which are divided into three expectations covering about 456 pages; the novel includes 87 analepses, 21 prolepses, 7 ellipses, 73 summaries, 31 descriptive pauses, and 233 scenes. In addition, the research has concluded that the ratio of narration time to narrated time slows continually from the First Expectation towards the Second Expectation up to the end. The story as presented according to Pip's speech took 28 years. 


\section{References}

Abrams , M,H. (1993) A Glossary of literary Terms .6th ed. Holt, Rinehart and Winston, inc. New York ; Harcourt Brace College Publishers.

Abrams , M,H. et al (1967) The Norton Anthology of English Literature. Vol.1.USA

Bal, Mieke. (1985) Narratology. Trans. Christine van Boheemen. Toronto: U of Toronto P.

Crystal, David.( 1987).The Cambridge encyclopedia of language. Cambridge, England: www.librarything.com/work/273) Cambridge University.

Cody, David. Dickens: A Brief Biography, Hartwick College. http://www.victorianweb.org/authors/dickens/dickensbio1.html

Dickens, Charles. By Angus Calder (1960-61) [1979]. Great Expectations. Great Britian,Penguin Books.

Gerard Genette (1980) Narrative Discourse, New York: Cornell University Press,.(1983).

Nouveau discours du récit. Paris: Seuil [1983] (1988) .------------------ .Narrative Discourse Revisited. Trans. Jane E. Lewin Ithaca: Cornell UP.

Hugh C. Holman (1972) A Handbook to literature 4thedition . USA . The Odyssey press.

Imad, Khalid Madi (2008) The structure of the Novel, AbdAllah Algazali;A study in narrative techaniques in the narrative Tabout.M.A. Omar Alokhtar university ..Libya.

Onega, Susan; García, Landa, José, Angel. (1996). Narratology: London: Longman.

Ricouer.P.(1985) Time and the Narrative. London. University of Chicago press,Ltd.

Rimmon-Kenan, S. (1983) Narrative fiction, London and New York: Routledge

Rimmon-Kenan, S. (1983) Narrative Fiction: Contemporary Poetics.London.Methuen.

Todorov, Tzvetan. 1969. Grammaire du Décameron. Mouton: The Hague. 